\title{
Biocompatibility evaluation of sputtered zirconium-based thin film metallic glass-coated steels
}

This article was published in the following Dove Press journal:

International Journal of Nanomedicine

I October 2015

Number of times this article has been viewed

\section{Balasubramanian \\ Subramanian' \\ Sundaram Maruthamuthu ${ }^{2}$ Senthilperumal Thanka \\ Rajan'}

'Electrochemical Material Science Division, ${ }^{2}$ Corrosion and Materials Protection Division, Central Electrochemical Research Institute, Karaikudi, India
Correspondence: Balasubramanian Subramanian

Electrochemical Materials Science

Division, Central Electrochemical

Research Institute, Karaikudi, 630006,

Tamil Nadu, India.

$\mathrm{Tel}+9 \mid 456524$ I538

Fax +914565227713

Email subramanianb3@gmail.com
Abstract: Thin film metallic glasses comprised of $\mathrm{Zr}_{48} \mathrm{Cu}_{36} \mathrm{Al}_{8} \mathrm{Ag}_{8}$ (at.\%) of approximately $1.5 \mu \mathrm{m}$ and $3 \mu \mathrm{m}$ in thickness were prepared using magnetron sputtering onto medical grade 316L stainless steel. Their structural and mechanical properties, in vitro corrosion, and antimicrobial activity were analyzed. The amorphous thin film metallic glasses consisted of a single glassy phase, with an absence of any detectable peaks corresponding to crystalline phases. Elemental composition close to the target alloy was noted from EDAX analysis of the thin film. The surface morphology of the film showed a smooth surface on scanning electron microscopy and atomic force microscopy. In vitro electrochemical corrosion studies indicated that the zirconium-based metallic glass could withstand body fluid, showing superior resistance to corrosion and electrochemical stability. Interactions between the coated surface and bacteria were investigated by agar diffusion, solution suspension, and wet interfacial contact methods. The results indicated a clear zone of inhibition against the growth of microorganisms such as Escherichia coli and Staphylococcus aureus, confirming the antimicrobial activity of the thin film metallic glasses. Cytotoxicity studies using L929 fibroblast cells showed these coatings to be noncytotoxic in nature.

Keywords: thin film metallic glasses, sputtering, biocompatibility, corrosion, antimicrobial activity

\section{Introduction}

Of the extensive family of glasses, metallic glasses are probably the youngest, and have a number of favorable characteristics, including amorphicity and high strength. Metallic glasses are typically hard and strong, free of grain boundaries and dislocations, and have excellent surface flatness and a high resistance to corrosion. ${ }^{1,2}$ They represent a new class of structural and functional materials with extraordinary properties, including high strength at low temperature, large elastic limits, high toughness, and thermal-forming properties, owing to their microstructure, which lacks long-range order atomic periodicity. ${ }^{3}$ Glassy alloys based on metallic elements such as $\mathrm{Zr}$, Ti, $\mathrm{Cu}$, and $\mathrm{Ni}$ have high-fracture strength with good toughness. Among these, Zr-based and $\mathrm{Cu}$-based alloys are significant because of their strong glass-forming ability and good mechanical properties. ${ }^{4}$ The high glass-forming ability in the $\mathrm{Zr}-\mathrm{Cu}-\mathrm{Ag}-\mathrm{Al}$ alloy system is due to denser local atomic packing and the smaller difference in Gibbs free energy between amorphous and crystalline phases. ${ }^{5}$ Addition of Ag can enhance the glass-forming ability as well as the stabilization of supercooled liquid of the $\mathrm{Cu}-\mathrm{Zr}$ alloy. The $\mathrm{Cu}_{45} \mathrm{Zr}_{45} \mathrm{Ag}_{10}$ glassy alloy also exhibits a high-fracture strength of 1,800 $\mathrm{MPa}$ and distinct plastic strain of over $0.2 \% .{ }^{6}$ These unique properties make metallic 
glass alloys highly feasible for biomedical implant applications. The selection criteria for a biomaterial include the material's properties and biocompatibility, and the ability to fabricate the desired shapes. Development of bulk metallic glasses (BMGs) is in progress, but they are costly and cannot be reproduced on a sufficient scale for use as a structural material.

Among the metals, 316L stainless steel (SS) is used in the medical field as an implant material due to its unique properties of biocompatibility and low cost. ${ }^{7}$ Unfortunately, 316L $\mathrm{SS}$ is not only susceptible to pitting corrosion, but can also cause an allergic reaction in the human body due to the release of Ni ions. The cells of mucous membranes can be affected by low concentrations of dissolved metal ions when they are in direct contact with the alloy. Hamano ${ }^{8}$ reported that $\mathrm{Ni}$ ions released from dental alloys can accumulate in cells over time, and this may have multiple harmful effects. Also in a typical body environment, 316L SS undergoes corrosion by body fluids and release metallic ions which would result in the reduction of their biocompatibility. ${ }^{7}$ Implanted materials in direct contact with tissues must not have any toxic, irritating, allergic, or carcinogenetic action. ${ }^{9}$ The high ionic strength, warm temperature, and high number of microorganisms in the human body can cause biodegradation of implant materials such that the patient may be exposed to corrosive products and suffer unwanted bioreactions. ${ }^{10}$ To protect and enhance metallic implants from wear and corrosion and to improve their biocompatibility, substantial surface modification techniques and coatings have been used to deposit a variety of functional coatings on the surfaces of metallic implants. Surface modifications are often undertaken to biomedical implants to improve their resistance to corrosion and wear, surface texture, and biocompatibility.

Currently, several studies are focusing on fabricating thin film metallic glasses (TFMGs) by a physical vapor deposition (sputtering) process, with a wide range of compositions and microstructures. Surface modification of the implantable substrate SS can be achieved by TFMG for bioimplants. The vacuum sputtering process, in which vapor-solid deposition transits the elements from the target to the substrate surface via ion bombardment, has a much higher critical cooling rate than that in traditional liquid-solid fabrication, and is an achievable way of forming metallic glass. ${ }^{11}$ Local crystallization and microsegregation are avoided in the sputtering process, and the TFMGs deposited usually have a uniform composition. Dense and suitably adhesive films with a controlled elemental composition can be produced by the sputtering technique. ${ }^{12} \mathrm{Zr}$-based TFMGs have unique properties owing to their amorphous nature, such as being free of grain boundaries, lack of segregation, and isotropy, high strength and toughness, good flexibility, and good corrosion resistance. ${ }^{13,14}$ Lower concentration of $\mathrm{Al}$ and $\mathrm{Ag}$ in Zr based metallic glass can enhance its thermal stability and homogeneity. ${ }^{15} \mathrm{Zr}-\mathrm{Cu}-\mathrm{Al}-\mathrm{Ag}$ TFMG prepared by sputtering with a single target device shows superior glass-forming ability, and coatings containing $\mathrm{Cu}$ and $\mathrm{Ag}$ constituents have significant antimicrobial properties. Multicomponent metallic glass films exhibit good mechanical properties, and wide supercooled liquid regions are the best match to their BMG, which suggests many biomaterial applications.

Zr-based alloys have superior strength (GPa), a high elastic strain limit (2\%), and a relatively low Young's modulus (50-100 GPa). ${ }^{16}$ Compared with crystalline metallic biomaterials, such as $\mathrm{Ti}$ and $\mathrm{SS}$, metallic glasses have a significantly lower modulus, which implies better load transfer to the surrounding bone and the potential for good stress-shielding. Schroers et al reported that Zr-based alloys in their amorphous and crystalline states support cell growth. NIH3T3 fibroblasts formed monolayers and attached firmly onto Zr-based BMGs over a period of 48 hours. ${ }^{18}$ Jin et al have developed a series of Ni-free Zr-based BMGs with the composition $\left(\mathrm{Zr}_{\mathrm{x}} \mathrm{Cu}_{100-\mathrm{x}}\right)_{80}\left(\mathrm{Fe}_{40} \mathrm{Al}_{60}\right)_{20}$ (where $\mathrm{x}$ is 62-81) that show excellent glass-forming ability and very good biocompatibility, similar to that of Ti-6Al-4V alloy. ${ }^{19}$ The biocompatibility can be further enhanced by a simple surface treatment consisting of passivation with $30 \% \mathrm{HNO}_{3}$ due to stabilization of the $\mathrm{Zr}$ oxide formed on the BMG surface, which blocks the dissolution of toxic ions. ${ }^{20}$ Monfared et al found that $\mathrm{Zr}_{60} \mathrm{Cu}_{20} \mathrm{Fe}_{10} \mathrm{Al}_{10} \mathrm{BMG}$ showed a higher passive region compared with that of $\mathrm{Zr}_{60} \mathrm{Cu}_{22.5} \mathrm{Fe}_{7.5} \mathrm{Al}_{10}$; however, these BMGs exhibited lower resistance to pitting corrosion when compared with crystalline biomaterials. ${ }^{17}$

This paper reports on the fabrication of amorphous $\mathrm{Zr}_{48} \mathrm{Cu}_{36} \mathrm{Al}_{8} \mathrm{Ag}_{8}$ (at.\%) thin films from a polycrystalline target using DC magnetron sputtering. Structural and mechanical characterization was carried out on these films when coated over SS substrates. The coated substrates were screened for their biocompatibility and investigated for possible use in implants.

\section{Materials and methods Preparation of Zr-based TFMG}

A sputtering target of $\mathrm{Zr}_{48} \mathrm{Cu}_{36} \mathrm{Al}_{8} \mathrm{Ag}_{8}$ (at.\%) alloy was prepared by the vacuum arc-melting technique. Appropriate amounts of pure (99.99\%) Zr, Cu, Al, and Ag were weighed and arc-melted under an argon atmosphere in a water-cooled 
copper die. Arc-melting was performed many times to obtain a uniform distribution of all the elements in the target. The composition of the target using X-ray fluorescence analysis was found to be $\mathrm{Zr}_{48} \mathrm{Cu}_{36} \mathrm{Al}_{8} \mathrm{Ag}_{8}$ (at.\%), which was in excellent agreement with the initial precursors used. The target was polycrystalline, as confirmed by X-ray diffraction. The $\mathrm{Zr}_{48} \mathrm{Cu}_{36} \mathrm{Al}_{8} \mathrm{Ag}_{8}$ specimen was cut and polished to the required dimensions ( $50 \mathrm{~mm}$ in diameter and $3 \mathrm{~mm}$ thick) to suit the target holder, and the $\mathrm{Zr}-\mathrm{Cu}-\mathrm{Al}-\mathrm{Ag}$ thin films were then deposited on 316L SS substrates using a DC magnetron sputtering system. The sputtering conditions used for preparation of the TFMGs are given in Table 1. Prior to deposition, the sputtering chamber was evacuated to a base pressure of $3 \times 10^{-6}$ mbar, and high purity (grade 1 ) argon was used as the sputtering gas.

\section{Characterization of TFMG}

The amorphous nature of the TFMG was recorded using a Bruker D8 Advance X-ray diffractometer with $\mathrm{Cu} \mathrm{K}$ radiation of $\lambda=0.15406 \mathrm{~nm}$. The morphology of the TFMG and direct bacterial attachment thereto was characterized using a Zeiss Supra 55VP field emission scanning electron microscope (SEM). The composition of the target and the TFMG were identified using an Horiba XGT-2700 X-ray analytical microscope. Surface morphology was tested using an Agilent 5500 atomic force microscope. Epifluorescent images were taken using a Nikon E200 Coolpix epifluorescence microscope. A micro scratch test was carried out for estimating critical loads based on scratching for a $4 \mathrm{~mm}$ scratch length using a CSM Instruments Micro-Combi Tester. Five scratch tests were done in one face, at a spacing of $0.3-0.5 \mathrm{~mm}$ and were arranged to obtain the mean critical loads. This technique involves generating a controlled scratch with a sharp tip on a selected area. The diamond tip is drawn across the coated surface under constant, incremental, or progressive load. At a certain load, the coating will start to fail. The minimum load at which adhesive failure occurs is called the critical load (Lc), and is also known as adhesion

Table I Deposition parameters used for the sputtering process

Target

Substrate

Target-substrate distance

Substrate temperature

Base pressure

Working pressure (Ar)

Power

Deposition time
$\mathrm{Zr}_{48} \mathrm{Cu}_{36} \mathrm{Al}_{8} \mathrm{Ag}_{8}$ Stainless steel, glass

$6 \mathrm{~cm}$

Room temperature

$8 \times 10^{-6} \mathrm{mbar}$

$3 \times 10^{-3} \mathrm{mbar}$

$30 \mathrm{~W}$

2 hours strength, which is the stress required to remove a coating from a substrate. ${ }^{21}$ Critical loads are very precisely detected by means of an acoustic sensor attached to the load arm and the data are collected by appropriate sensors attached to the indenter holder. If the critical load is higher, more force has to be applied to the sample for failure, meaning that the sample is more resistant. Critical loads for the first crack event (Lc1), first delamination (Lc2), and total delamination (Lc3) were determined from the frictional force and acoustic emission data. The maximum load applied in this experiment was $15 \mathrm{~N}$. The nanomechanical test was carried out using a Berkovich pyramidal-shaped indenter tip. At least 20 indentations in each sample were performed to verify the accuracy of the indentation data.

The electrochemical behavior and corrosion properties of the fully amorphous TFMGs $(1.5 \mu \mathrm{m}$ and $3 \mu \mathrm{m}$ in thickness $)$ and bare SS 316L alloys were studied in simulated body fluid prepared from analytical reagent grade chemicals and distilled water as reported by Kukubo et al. ${ }^{22}$ Potentiodynamic polarization measurements and an AC impedance test were conducted using a Parstat 2273 advanced electrochemical workstation in a three-electrode cell with PowerSuite software. The electrochemical behavior of the TFMG alloys was studied by polarization curves in the three-electrode cell at $37^{\circ} \mathrm{C}$. The counter and reference electrodes were platinum wire and saturated calomel reference electrode respectively. TFMG-coated substrates of different thicknesses were used as the working electrode. The distance between the reference and working electrodes was fixed at a constant value throughout the test. For the corrosion experiment, the samples were sealed with epoxy resin in such a way that a cross-section of approximately $10 \mathrm{~mm}^{2}$ was left exposed. Before potentiodynamic polarization measurements and the $\mathrm{AC}$ impedance test, the specimens were allowed to stabilize in simulated body fluid until the open circuit potential changed by no more than $2 \mathrm{mV}$ every 5 minutes. The polarization scan was done at a scan rate of $0.166 \mathrm{mV}$ per second. The corrosion current density $\left(\mathrm{I}_{\text {corr }}\right)$, corrosion potential $\left(\mathrm{E}_{\text {corr }}\right)$, and corrosion rate was determined by the Tafel extrapolation method from polarization curves.

Electrodes with the same specifications as those used in the polarization studies were used for impedance studies. In order to establish the open circuit potential, prior to measurements, the sample was immersed in the solution for approximately 60 minutes. Impedance measurements were taken after attainment of steady state; an AC signal of $10 \mathrm{mV}$ amplitude was applied and impedance values were measured for frequencies from $0.01 \mathrm{~Hz}$ to $100 \mathrm{kHz}$. 


\section{Antibacterial activity tests}

Both Gram-positive (Staphylococcus aureus) and Gramnegative (Escherichia coli) cultures were used to study the antibacterial properties of the Zr-based TFMG. Each strain (HiMedia, Mumbai) was cultured in nutrient broth and incubated areobically at $37^{\circ} \mathrm{C}$ overnight. Interactions between the coated surfaces and bacteria were investigated using three techniques, ie, the agar diffusion, solution suspension, and wet interfacial contact methods. The ability of the TFMG to form a zone of inhibition was monitored in a culture of $S$. aureus and E. coli by agar diffusion, which was achieved by preparing an agar medium that was autoclaved at $121^{\circ} \mathrm{C}$ for 15 minutes; the solution was then cooled and poured into sterile Petri plates and allowed to solidify and dry at room temperature. A bacterial concentration of $4.5 \times 10^{5}$ colony forming units $/ \mathrm{mL}$ in cells from a single strain were spread over the agar plate using an inoculation loop over the surface of the agar plates. The $10 \mathrm{~mm}$ diameter TFMG-coated SS specimens were gently pressed over the surface of the agar plates. After overnight incubation at $37^{\circ} \mathrm{C}$, the zone of inhibition was formed on the TFMG-coated SS and not on the SS control. Reduction in bacterial viability was monitored by measuring total viable counts for different time intervals $(4,8$, and 10 hours). Percentage reduction in bacterial count was calculated using the formula:

$$
\% \text { killing efficiency }=\frac{\begin{array}{l}
\text { Viable count }(0 \mathrm{~h})- \\
\text { Viable count }(\text { time interval })
\end{array}}{\text { Viable count }(0 \mathrm{~h})} \times 100
$$

The wet interfacial contact method involves consistent direct contact between the mixed E. coli and S. aureus bacteria and the sample surface. In this study, a mixture of $E$. coli and $S$. aureus bacteria with buffer $\left(4.5 \times 10^{5}\right.$ colony forming units $/ \mathrm{mL}$ in phosphate-buffered solution) was suspended on the TFMG-coated substrate, and the bacterial cells were fixed onto TFMG using glutaraldehyde after 24 hours. The sample was washed several times, dried at $37^{\circ} \mathrm{C}$ for 12 hours, and gold-sputtered for analysis by SEM. Disruption of the bacterial cell membrane with respect to incubation time was visualized by epifluorescence microscopy. Fluorescein isothiocyanate (FITC) and propidium iodide (PI) dual stains were used to identify living/dead cells in the bacterial populations. ${ }^{23}$ PI penetrates only damaged cells and binds the DNA-emitting red color, whereas FTIC remains exterior to the undamaged cell walls, giving rise to green emission.
Approximately $0.5 \mu \mathrm{L}$ of dual FITC-PI stain (1:1\%) was added to the bacterial samples, which were then incubated for 15 minutes. The excess stain was removed by rinsing with sterile distilled water and the specimen was examined under the epifluorescence microscope.

\section{Biocompatibility test}

Cytotoxicity was studied by assessing the response of L929 mouse fibroblast cells. A direct contact method based on International Organization for Standardization standard 10993 Part 5 was carried out on the test samples using SS 316L as the control. L929 cells were grown in culture flasks with Dulbecco's Minimum Essential Medium supplemented with $10 \%$ fetal bovine serum and incubated at $37^{\circ} \mathrm{C}$ and $5 \% \mathrm{CO}_{2}$ under humidified conditions. The cells were subcultured in 24-well plates using trypsinethylenediaminetetraacetic acid solution and allowed to form a monolayer. Once the cells attained confluency, test samples were kept in contact with cells and cultured for 72 hours. Live/dead cell staining was then performed to determine the number of viable and nonviable L929 cells. Cells cultured in the fiber module were evaluated for viability by double staining with fluorescein diacetate and PI. The test specimen containing cultured cells was treated with a solution containing $10 \mu \mathrm{g} / \mathrm{mL}$ fluorescein diacetate for 10 minutes and rinsed by dipping in phosphatebuffered saline. Cells were counterstained with PI $1 \mu \mathrm{g} / \mathrm{mL}$ for 2 minutes. The samples were then rinsed by further dipping in phosphate-buffered saline and observed under a Leica DMI6000 fluorescence microscope.

\section{Release of metal ions from TFMG}

The coated samples were dipped in simulated body fluid, stored at $37^{\circ} \mathrm{C}$, collected after 7,14 , and 21 days, and investigated for ion release by atomic absorption studies.

\section{Result and discussion \\ Structural and compositional analysis}

Figure 1 shows the $\mathrm{X}$-ray diffraction spectra for the $\mathrm{Zr}-\mathrm{Cu}$ Al-Ag TFMG and the target used for deposition. The polycrystalline nature of the target and the amorphous nature of TFMG was confirmed by X-ray diffraction. There was no detectable crystalline peak in the $2 \theta$ range of $20^{\circ}-80^{\circ}$, but a broad diffuse peak was observed with a maxima of $37.50^{\circ}$ at $2 \theta$. This indicates that the $\mathrm{Zr}-\mathrm{Cu}-\mathrm{Al}-\mathrm{Ag}$ TFMG has a glassy structure achieved by a DC magnetron sputtering process from the polycrystalline target. The major contributor to the formation of metallic glass is the rapid cooling rate. Longer 


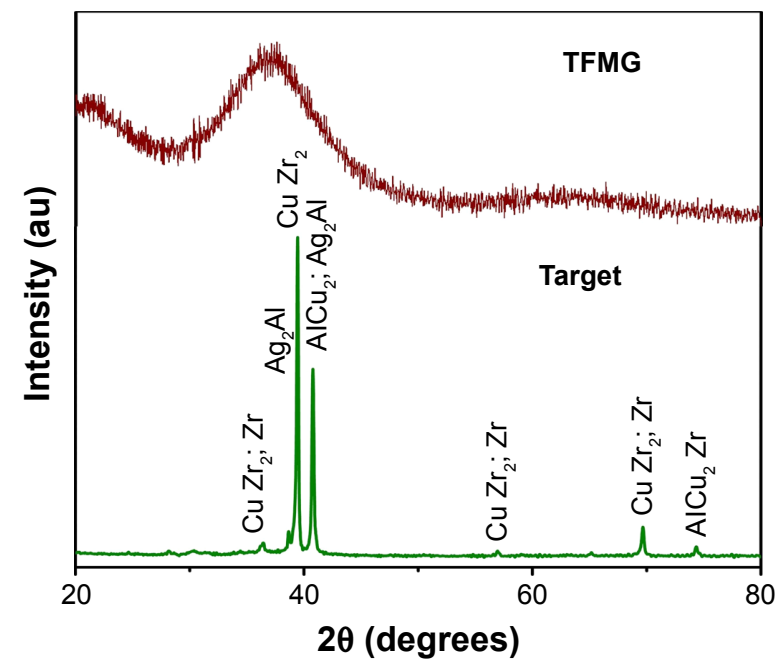

Figure I X-ray diffraction pattern of $\mathrm{Zr}_{48} \mathrm{Cu}_{36} \mathrm{Al}_{8} \mathrm{Ag}_{8}$ thin film metallic glass. Abbreviation: TFMG, thin film metallic glass.

cooling rates from the melting point will result in larger grains because the atoms have more time to order themselves into crystals. The rate of cooling can increase to the point that the grains would not only become very small, but soon cease to exist altogether. The polycrystalline structured target containing elements such as $\mathrm{Zr}$, $\mathrm{Al}$, and $\mathrm{Cu}$ can reach critical cooling rates of $1 \mathrm{~K} / \mathrm{sec}$, at which an amorphous structure can be obtained in the sputtering process. The surface morphology of the specimen was measured by atomic force microscopy, as shown in Figure 2. The morphology shows no visible pores or cracks in the amorphous sample, indicating a densely packed atomic arrangement on the sample. The surface profile was uniform and smooth because there were no grain boundaries in the amorphous film. The deposited film had an average surface roughness of $0.37 \mathrm{~nm}$ (root mean squared roughness $0.45 \mathrm{~nm}$ ). A similar observation was made from the SEM image shown in Figure 3.

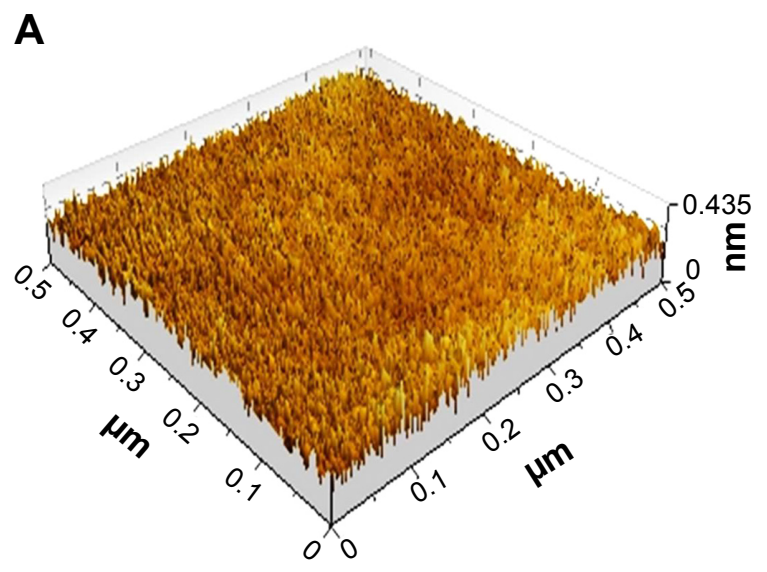

The X-ray fluorescence spectrum (Figure 4) showed a uniform distribution of elements in the target and TFMG, and their concentration data clearly revealed the presence of $\mathrm{Zr}$, $\mathrm{Cu}, \mathrm{Al}$, and $\mathrm{Ag}$. The composition of the amorphous film was found to be $\mathrm{Zr}$ (43.29 at.\%), $\mathrm{Cu}$ (49.23 at.\%), $\mathrm{Al}$ (4.09 at.\%), and $\mathrm{Ag}$ (3.39 at.\%). A difference was observed between the composition of the sputtering target and the sputtered film. In an alloy target the sputtering yields may vary for the different elements. The sputtering yield depends on the atomic mass and the surface binding energy. The sputtering yield is the quantity of material removed per incident ion. The composition in the films also follow the sputtering yields of the respective elements. However, the $\mathrm{Ag}$ concentration in the films are low, probably because of the higher binding energy. A similar observation is reported in the literature. ${ }^{24}$ Moreover, scattering in plasma varies with the scattering cross-section of the sputtered species, which could also be a reason for the difference in composition between the film and the target.

\section{Mechanical properties}

Scratch resistance of the samples was tested and the result for the tested surface is shown in Figure 5. The critical loads corresponding to $\mathrm{Lc} 1, \mathrm{Lc} 2$, and $\mathrm{Lc} 3$ are $1.5 \pm 0.19 \mathrm{~N}, 1.71 \pm 0.13 \mathrm{~N}$, and $10.23 \pm 0.93 \mathrm{~N}$, respectively, for the $\mathrm{Zr}-\mathrm{Cu}-\mathrm{Al}-\mathrm{Ag}$ TFMG coated onto the SS substrates. The observed higher critical load for Lc3 clearly shows that the specimen is more resistant to scratches and cosmetic defects. The friction coefficient is the ratio of the frictional force to the normal load. Frictional force results from the classic interaction between the indenter and the coating. Lower shear strength between the indenter and the coated surface would result in a lower frictional force, and thus a lower friction coefficient. ${ }^{21}$ The

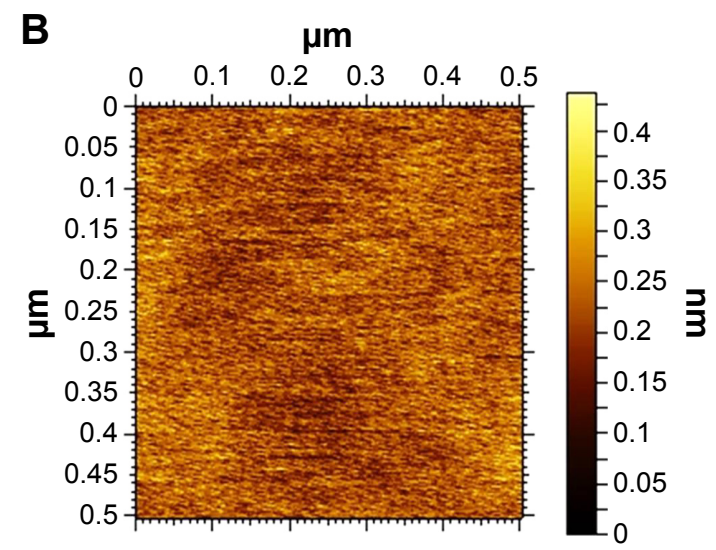

Figure 2 Surface topography of $\mathrm{Zr}_{48} \mathrm{Cu}_{36} \mathrm{Al}_{8} \mathrm{Ag}_{8}$ thin film metallic glass. Notes: (A) Three-dimensional view, (B) two-dimensional view. 


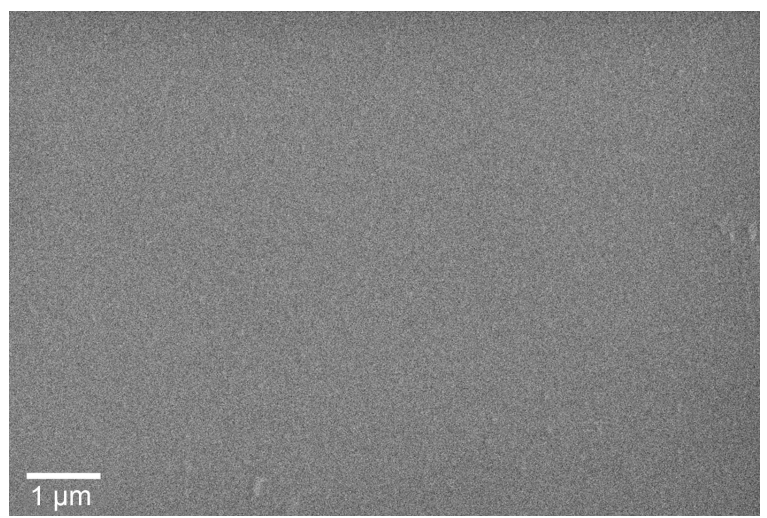

Figure 3 Scanning electron micrograph of the surface of the $\mathrm{Zr}_{48} \mathrm{Cu}_{36} \mathrm{Al}_{8} \mathrm{Ag}_{8}$ thin film metallic glass.

friction coefficients for the three critical loads, ie, Lc1, Lc2, and Lc3, were $0.24,0.27$, and 0.32 , respectively, and were almost constant, indicating that the coating was not totally delaminated. After Lc3, the friction coefficient and frictional force increased suddenly to 0.63 implying the film has been completely damaged. The observed increase in frictional force for higher loads is caused by ploughing and buckling mechanisms. ${ }^{25}$ Nanoindentation is a reliable method for investigating Young's modulus and additional measurements, such as hardness, stiffness, elastic modulus, and fracture toughness. Figure 6 shows the loading displacement curves obtained for TFMG with a maximum load of $15 \mathrm{mN}$. Nanoindentation experiments take into account the thickness of the coating. In order to avoid any influence from the substrate, the maximum depth should not surpass one tenth of the overall film thickness. The thickness of the film was 3 microns and the indentation depth was $290.24+3.85 \mathrm{~nm}$. Therefore, there was no effect from the substrate. The peak load $\left(\mathrm{P}_{\max }\right)$, the displacement at peak load $\left(\mathrm{h}_{\max }\right)$, and the initial unloading contact stiffness $(\mathrm{S}=\mathrm{dP} / \mathrm{dh}$, ie, the slope of the initial portion of the unloading curve), the reduced modulus is given by:

$$
\mathrm{E}_{\mathrm{r}}=(\pi)^{1 / 2} / 2 \times \mathrm{S} /\left(\mathrm{A}_{\mathrm{c}}\right)^{1 / 2}
$$
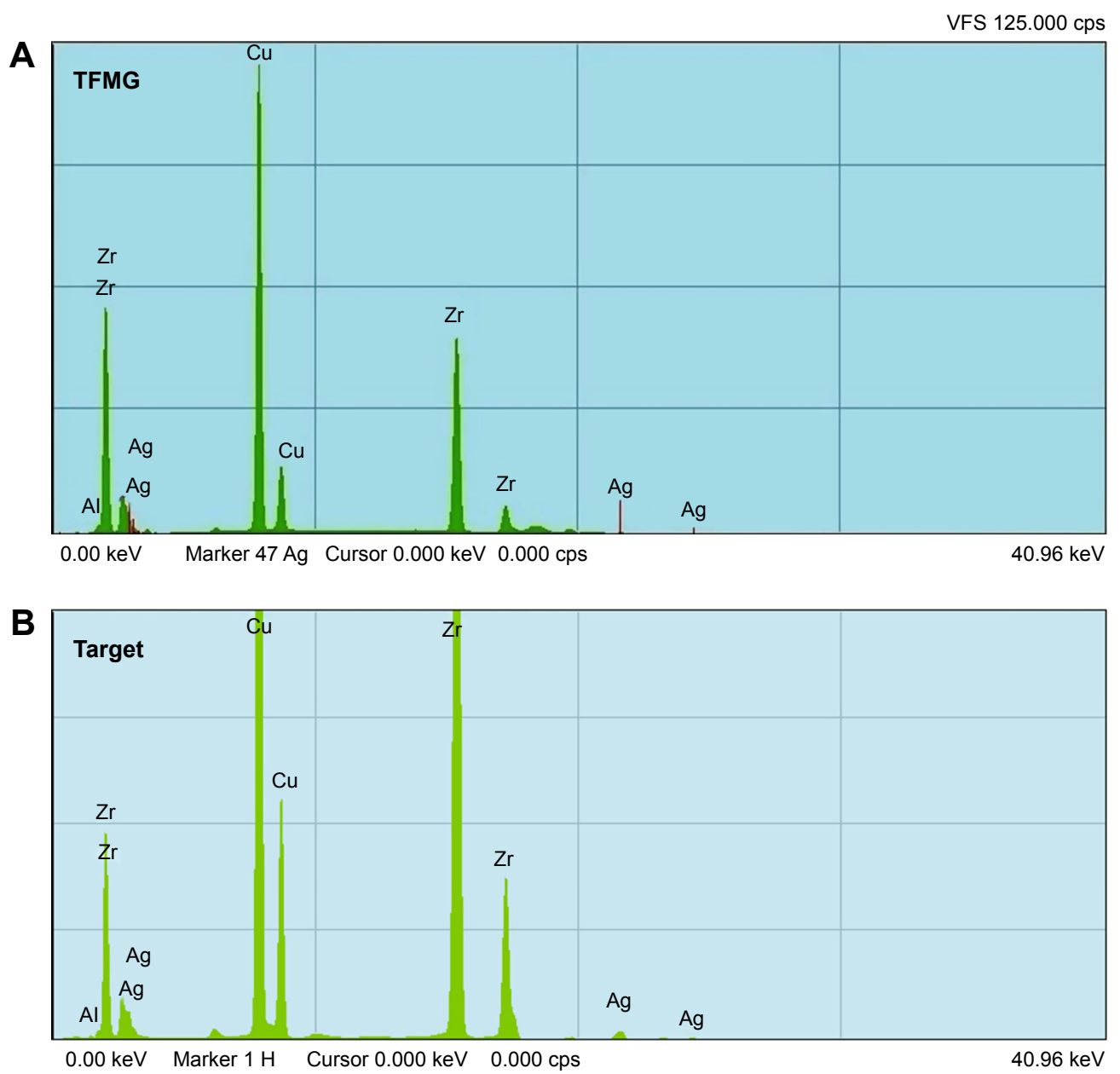

Figure 4 XRF spectra of the $\mathrm{Zr}-\mathrm{Cu}-\mathrm{Al}-\mathrm{Ag}(\mathbf{A})$ thin film metallic glass and (B) target. Abbreviations: XRF, X-ray fluorescence; TFMG, thin film metallic glass. 
A
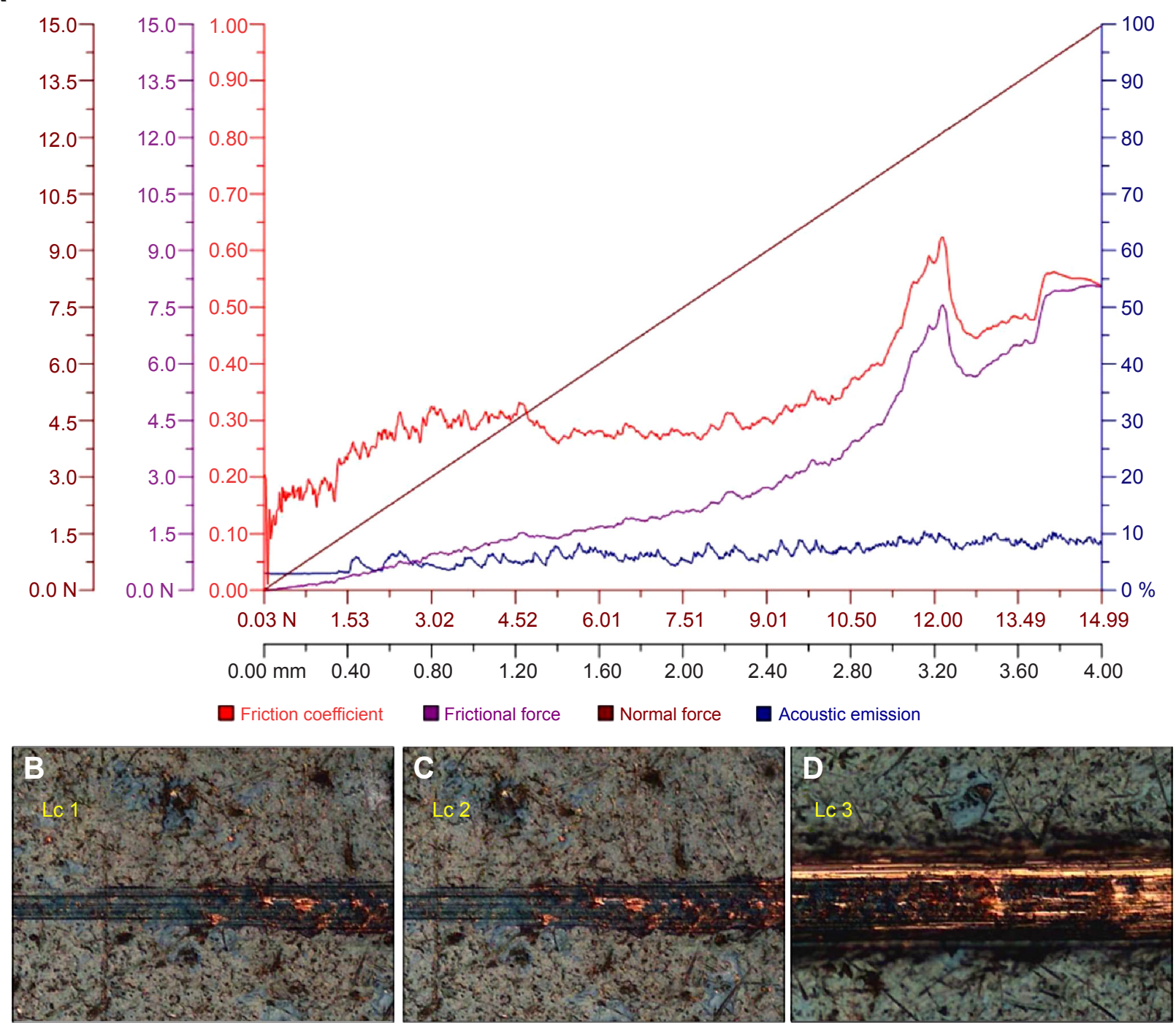

Figure 5 Scratch test results (A) Graph of variation of normal force, frictional force, friction coefficient and acoustic emission for a load. Scratch track on TFMG for (B) first critical load (Lcl); (C) second critical load (Lc2); (D) third critical load (Lc3).

where $\left(\mathrm{A}_{\mathrm{c}}\right)$ is the projected contact area and $\mathrm{E}_{\mathrm{r}}$, accounts for the fact that the measured displacement includes contributions from both the specimen and the indenter. For an ideal pyramidal tip (Berkovich), the projected contact area (A) in relation to the contact depth $\left(h_{c}\right)$ is given by:

$$
\mathrm{A}_{\mathrm{c}}=24.5 \mathrm{~h}_{\mathrm{c}}^{2}
$$

The contact depth $\left(\mathrm{h}_{\mathrm{c}}\right)$ is then calculated as:

$$
\mathrm{h}_{\mathrm{c}}=\mathrm{h}_{\max }-3 \mathrm{P}_{\max } / 4 \mathrm{~S}
$$

The hardness is determined from the maximum load $\left(\mathrm{P}_{\max }\right)$ divided by the projected contact area $\left(\mathrm{A}_{\mathrm{c}}\right)$ :

$$
\mathrm{H}=\mathrm{P}_{\max } / \mathrm{A}_{\mathrm{c}}
$$

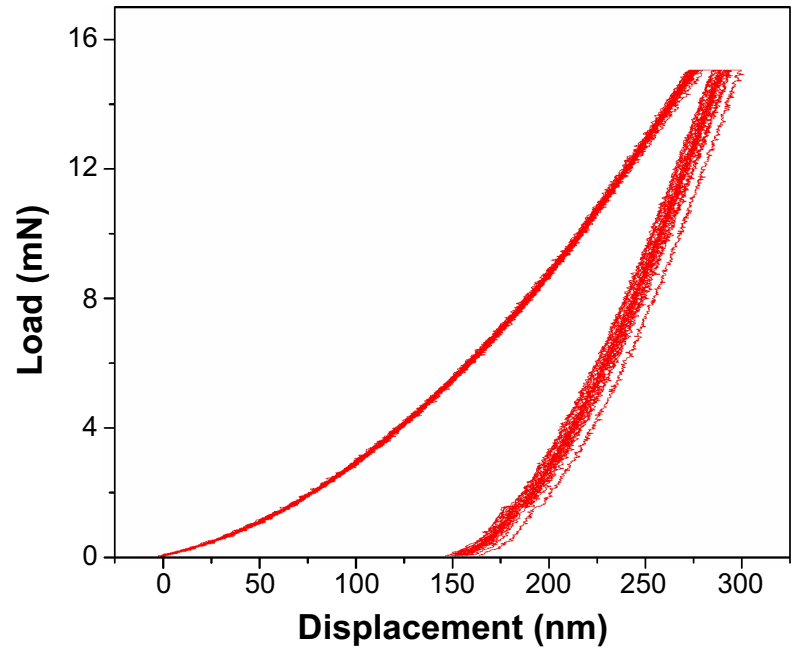

Figure $6 \mathrm{Load}$ versus displacement nanoindendation curve obtained for $\mathrm{Zr}_{48} \mathrm{Cu}_{36} \mathrm{Al}_{8} \mathrm{Ag}_{8}$ thin film metallic glass. 
The Young's modulus of the film $\left(\mathrm{E}_{\mathrm{f}}\right)$ can then be obtained from:

$$
1 / \mathrm{E}_{\mathrm{r}}=\left[\left(1-v_{\mathrm{f}}^{2}\right) / \mathrm{E}_{\mathrm{f}}\right]+\left[\left(1-v_{\mathrm{i}}^{2}\right) / \mathrm{E}_{\mathrm{i}}\right]
$$

where E and $v$ are Young's modulus and Poisson's ratio, respectively, and the subscripts, f and i, represent the film and the indenter, respectively (for a diamond indenter, $\mathrm{E}_{\mathrm{i}}=1,141 \mathrm{GPa}$ and $\left.v_{i}=0.07\right)$. Stiffness of the film was $0.185 \times 10^{6} \mathrm{~N} / \mathrm{m}$. The hardness and reduced modulus $\mathrm{E}_{\mathrm{r}}$ of TFMG was $9.33 \mathrm{GPa}$ and 117.35 GPa, respectively. Young's modulus of the TFMG $\left(\mathrm{E}_{\mathrm{f}}\right)$ was computed as $113.92 \mathrm{GPa}$. These values are lower than those for metallic implants with surface modification by hard ceramic coatings, but are comparable with the reported Young's modulus and hardness values of $120 \mathrm{GPa}$ and $7.8 \mathrm{GPa}$, respectively, for sputtered hydroxyapatite coatings. ${ }^{26,27}$ However, the measured values are higher than that reported for BMG which may be due to the difference in microstructure between the assputtered film and the bulk counterpart as well as the hardness calculation method. ${ }^{28}$

\section{Electrochemical corrosion in simulated body fluid}

A number of important corrosion parameters for the bare (uncoated) samples and the samples coated with TFMG (1.5 $\mu \mathrm{m}$ and $3.0 \mu \mathrm{m}$ in thickness) could be determined by measurement of potentiodynamic polarization in simulated body fluid, as shown in Figure 7. $\mathrm{E}_{\text {corr }}$ is used to evaluate the driving force for biocorrosion, and a system with a higher $\mathrm{E}_{\text {corr }}$ needs more energy to start a corrosion reaction. The $\mathrm{E}_{\text {corr }}$ of the bare (uncoated) samples and the

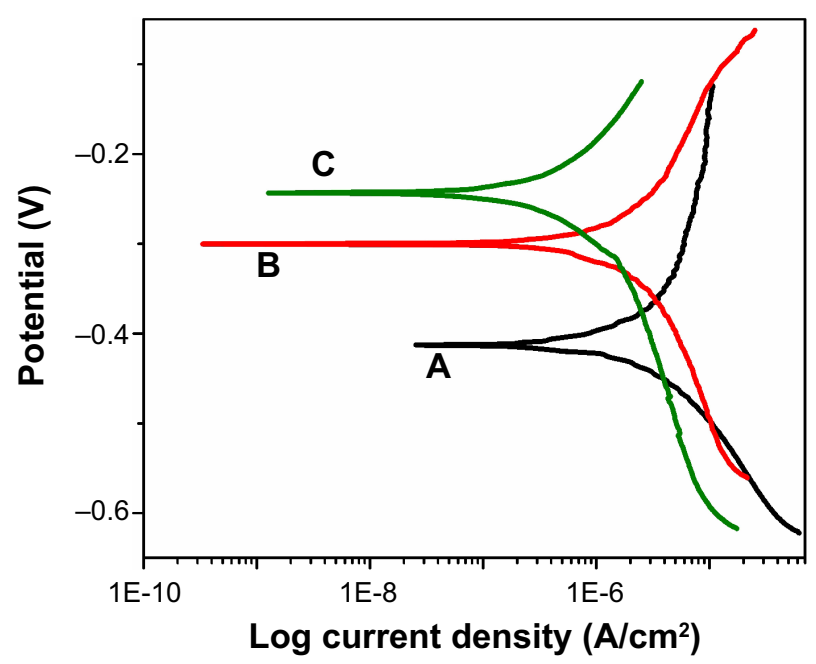

Figure 7 Tafel plots for (A) blank stainless steel substrate, (B) $1.5 \mu \mathrm{m}$ thick thin film metallic glass-coated stainless steel, and (C) $3 \mu \mathrm{m}$ thick thin film metallic glasscoated stainless steel in simulated body fluid.
TFMG-coated specimens $(1.5 \mu \mathrm{m}$ and $3.0 \mu \mathrm{m}$ thickness $)$ shown in Table 2 indicate a positive shift in $\mathrm{E}_{\text {corr }}$ values for the coated samples. Hence, the bare crystallized specimens have more opportunity to start a corrosion reaction due to the lower value of $\mathrm{E}_{\text {corr }}$. The $\mathrm{I}_{\text {corr }}$ is another important parameter that determines the activity of a corrosion reaction. The $\mathrm{I}_{\text {corr }}$ value was approximately $7.24 \times 10^{-6} \mathrm{~mA}$ for the bare specimen and approximately $4.82 \times 10^{-6}$ and $1.05 \times 10^{-6} \mathrm{~mA}$, respectively, for TFMG-coated specimens $1.5 \mu \mathrm{m}$ and $3.0 \mu \mathrm{m}$ in thickness. The lower $\mathrm{I}_{\text {corr }}$ values for the TFMGs again reflect their lower degree of electrochemical activity as compared with the bare specimen. The higher corrosion current observed for the bare substrate indicates that the biocorrosion reaction is significantly more severe for the bare crystalline substrate than for the coated amorphous samples.

The above $\mathrm{E}_{\text {corr }}$ and $\mathrm{I}_{\text {corr }}$ data consistently indicate that the fully amorphous TFMG would show superior bioelectrochemical resistance. Between the corrosion rates calculated for the bare and coated samples, the corrosion rate decreases and the protective efficiency increases with increasing thickness of TFMG. Electrochemical impedance spectra were performed for the bare and coated specimens, and the data obtained from the Nyquist plot shown in Figure 8 are presented in Table 2. In the Nyquist plot, the larger diameter of the semicircle indicates a higher resistance to corrosion. It is clear that the coated specimens have the highest $\mathrm{R}_{\mathrm{ct}}$ values and lower $\mathrm{C}_{\mathrm{d}}$, and hence high corrosion resistance.

\section{Cytotoxicity}

Fluorescent images of the blank SS control substrate and Zr-based TFMGs in contact with L929 fibroblast cells are shown in Figure 9A and B. Test samples, negative controls, and positive controls were placed on the cells in triplicate. After incubation at $37^{\circ} \mathrm{C} \pm 1^{\circ} \mathrm{C}$ for $24-26$ hours, the cell monolayer was examined microscopically for the response around the test samples. The reactivity can be graded as $0,1,2,3$, or 4 based on zone of lysis, vacuolization, detachment, and disintegration, respectively. Figure 9B indicates slight reactivity with the presence of a few malformed or degenerated cells, which is graded as 1 . As per International Organization for Standardization standard 10993 Part 5, achievement of a numerical grade $>2$ is considered to indicate a cytotoxic effect. Since the test material did not achieve a numerical grade $>2$, the material was considered not to be toxic. Further, the coated samples did not show increased levels of cytotoxic behavior in comparison with the biocompatible SS control when the materials were kept 
Table 2 Electrochemical corrosion parameters obtained for specimen in simulate body fluid

\begin{tabular}{|c|c|c|c|c|c|c|}
\hline Sample & $E_{\text {corr }}(\mathrm{mV})$ & $I_{\text {corr }}\left(\right.$ A) $\times 10^{-6}$ & $\begin{array}{l}\text { Corrosion rate } \\
(\mathrm{mpy}) \times 10^{-3}\end{array}$ & $\mathbf{R}_{\mathrm{ct}}(\Omega) \times 10^{4}$ & $C_{d l}(\mu F)$ & $\begin{array}{l}\text { Protective } \\
\text { efficiency \% }\end{array}$ \\
\hline 316 L SS blank & -412 & 7.2 & 2.13 & 0.36 & 2.5 & - \\
\hline $1.5 \mu \mathrm{m}$ TFMG/SS & -300 & 4.8 & 1.4 & 2.25 & 1.2 & 40.85 \\
\hline $3 \mu \mathrm{m}$ TFMG/SS & -243 & 1.0 & 0.31 & 2.66 & 1.09 & 85.428 \\
\hline
\end{tabular}

Abbreviations: SS, bare stainless steel; TFMG/SS, thin film metallic glass-coated stainless steel; $\mathrm{I}_{\text {corr }}$, corrosion current density; $\mathrm{E}_{\text {corr' }}$, corrosion potential.

in contact with fibroblast cells, and hence could be classified as non-cytotoxic material.

\section{Antibacterial activity}

Agar diffusion studies were carried out to measure the bacterial inhibition zone in agar medium due to the antibacterial activity of TFMG on the SS substrate versus the SS substrate alone as the control. It can be seen in Figure 10 that the zone of inhibition for the TFMG specimen is $2 \mathrm{~mm}$, whereas the control system shows bacterial growth over the bare SS without a zone of inhibition. The clear zone of inhibition formed around the TFMG specimen may be attributable to the presence of $\mathrm{Cu}$ and $\mathrm{Ag}$ ions. The agar diffusion method indicated that the specimen has antibacterial activity against E. coli and S. aureus.

A kinetic study using the solution suspension method was performed to study the antibacterial behavior of the TFMG specimen (Figure 11). Maximum killing of E. coli and $S$. aureus was observed at 12 hours after immersion, which may be due to greater interfacial contact between TFMG containing $\mathrm{Cu}$ ions and the E. coli and S. aureus bacteria. The results obtained from solution contact studies indicate the potential of

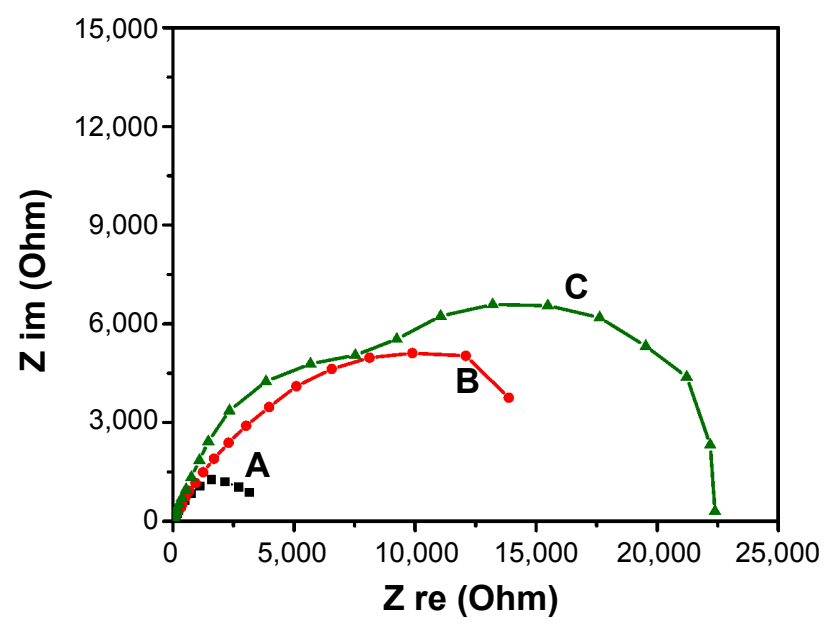

Figure 8 AC impedance studies of (A) blank stainless steel substrate, (B) $1.5 \mu \mathrm{m}$ thick thin film metallic glass-coated stainless steel, and (C) $3 \mu \mathrm{m}$ thick thin film metallic glass-coated stainless steel in simulated body fluid. the TFMG specimen prepared by the physical vapor deposition for use in bacterial destruction and disinfection.

Figure 12 shows the field emission SEM images for the wet solution contact method between the bacterial colonies of E. coli and $S$. aureus TFMG specimen. Figure 12A-C shows low magnification field emission SEM images of SS samples with and without a TFMG coating. The micrograph of SS alone (control system, Figure 12A and B) shows increased bacterial growth and heterogeneous bacterial colonies on the metal surface. Rod-shaped bacterial cells (E. coli) with tufts of flagella and round-shaped ( $S$. aureus) structures were noted on the surface of the control specimen. The bacterial cells could be visualized on higher magnification field emission SEM images, as shown in Figure 12B. The bacterial population on the TFMG specimen was considerably reduced (Figure 12C). It can be seen that the morphology

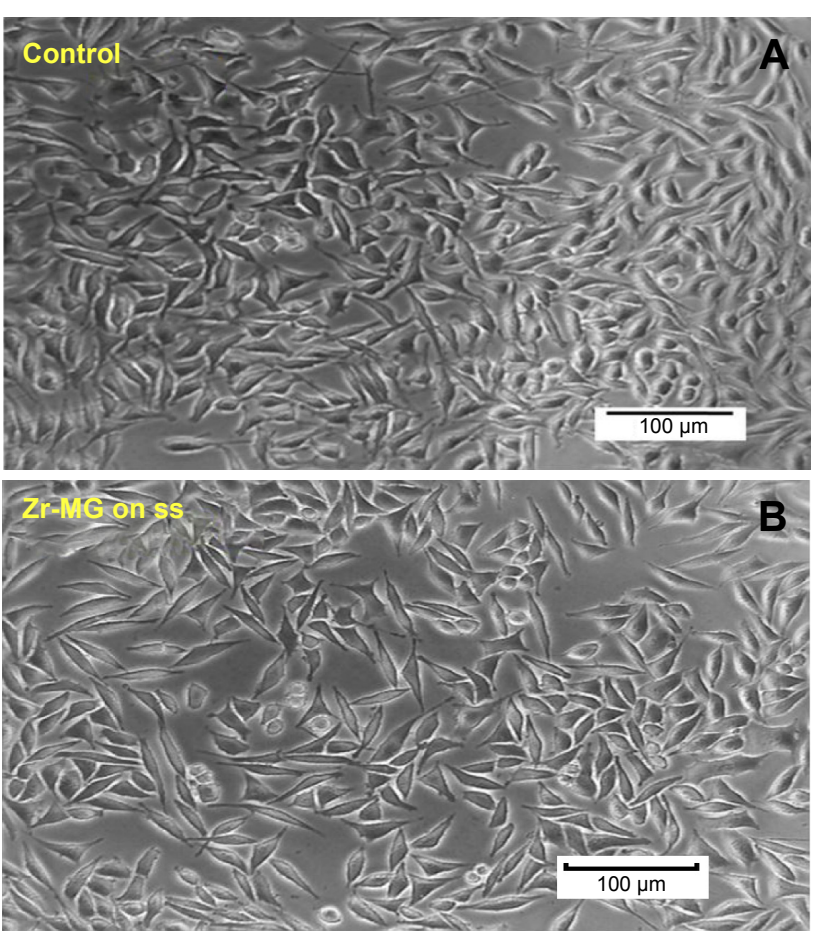

Figure 9 Contact between L929 fibroblast cells, (A) blank SS (control) and (B) TFMG. 
A

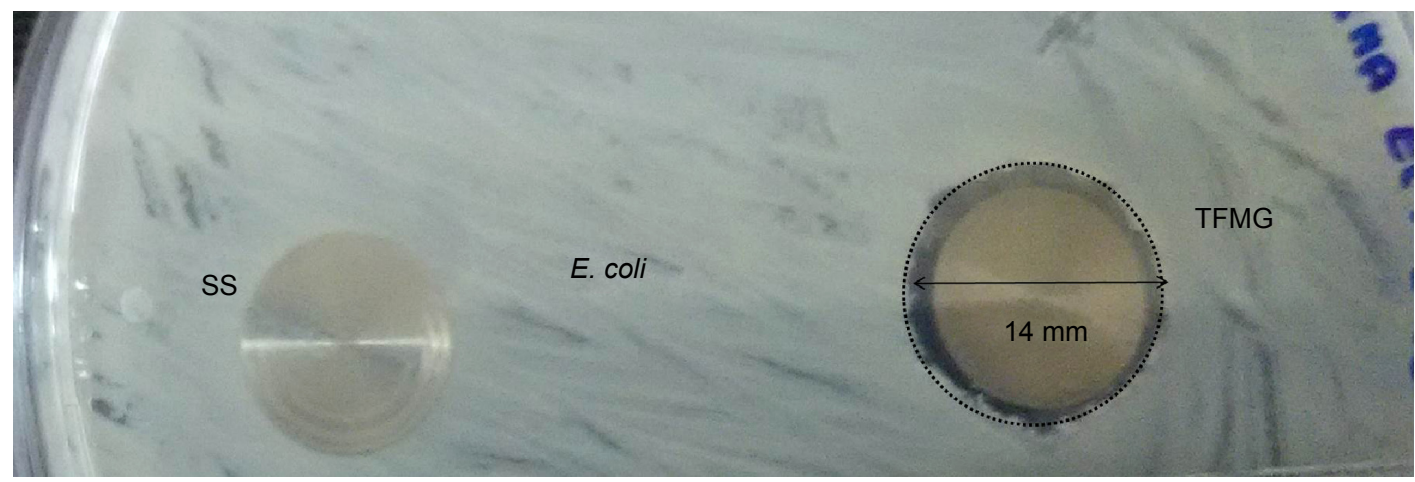

B

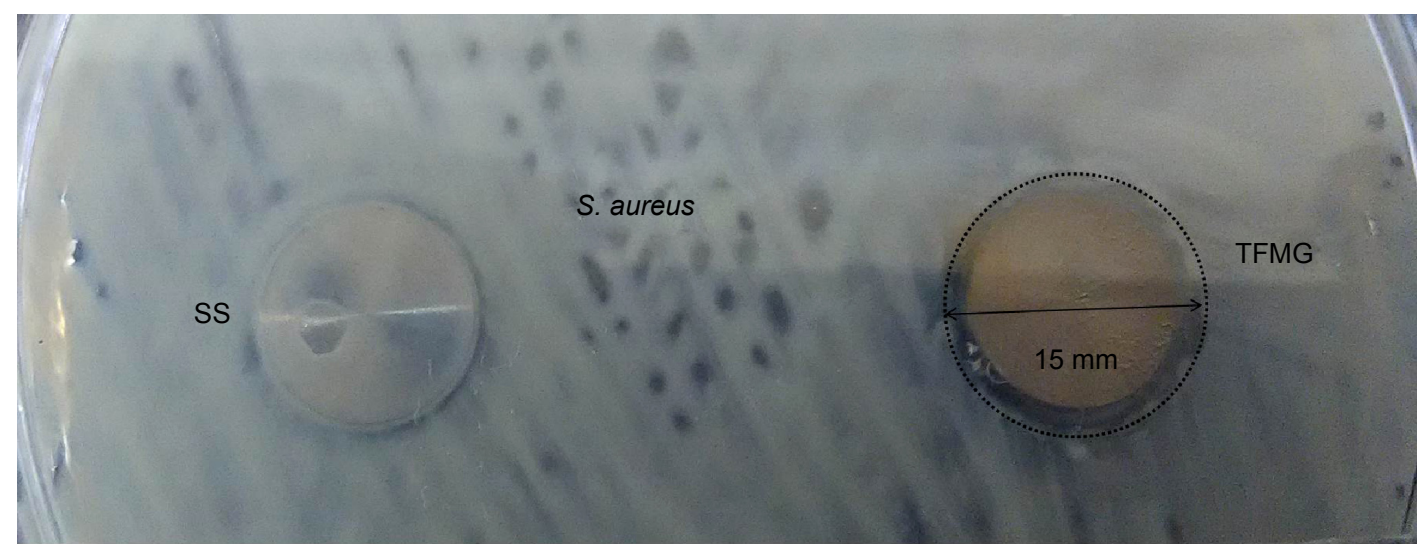

Figure 10 Zone of inhibition produced against (A) Escherichia coli and (B) Staphylococcus aureus bacteria on bare stainless steel and on thin film metallic glass-coated stainless steel.

Abbreviations: TFMG, thin film metallic glass; SS, stainless steel.

of the bacterial cells had changed significantly on the TFMG specimen (Figure 12D) when compared with the SS control (Figure 12B). Further bacterial cell damage was visualized by epifluorescent microscopy.

The killing of E. coli and S. aureus bacteria by TFMG on SS under wet conditions was visualized by epifluorescent microscopy (Figure 13). Identification of dead/living cells in the

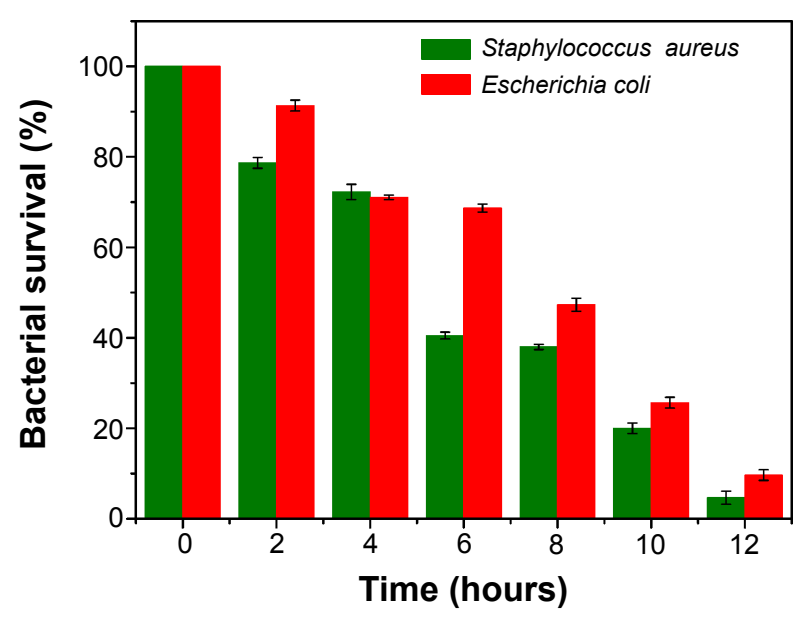

Figure II Bacterial killing efficiency versus time for a thin film metallic glass specimen against Escherichia coli and Staphylococcus aureus. bacterial population was done using FITC and PI dual stains. Living cells are stained green, while dead cells are stained red. Figure 13A and D shows epifluorescent microscopic images of $S$. aureus and E. coli prior to initiation of wet solution contact, and shows live bacterial cells stained green. The epifluorescence image of the bacterial colonies after 6 hours contact with the TFMG showed appearance of reddish color indicating dead bacterial species (Figures 13B and 13E). Most of the E. coli and $S$. aureus cells were destroyed after 12 hours, as seen in Figure $13 \mathrm{C}$ and $\mathrm{F}$. The results of the solution wet contact studies suggest that TFMG increases bacterial killing effectively.

The antibacterial activity is enhanced by weakly bonded $\mathrm{Cu}$ and $\mathrm{Ag}$ ions on the surface that can be easily released into the surrounding medium. It seems that the antimicrobial ability of this type of inorganic material depends not only on the active cation but also on the mineral carrier, as well as the interaction between them. Due to the weak interaction between $\mathrm{Ag}$ ions and the host layer, the Ag ions were released from the TFMG. The antimicrobial mechanism of the TFMG was mainly due to the slow release of Ag ions and its strength was related to the concentration of Ag ions in the medium. The cell walls of the viable bacteria were usually negatively charged due to functional groups, 

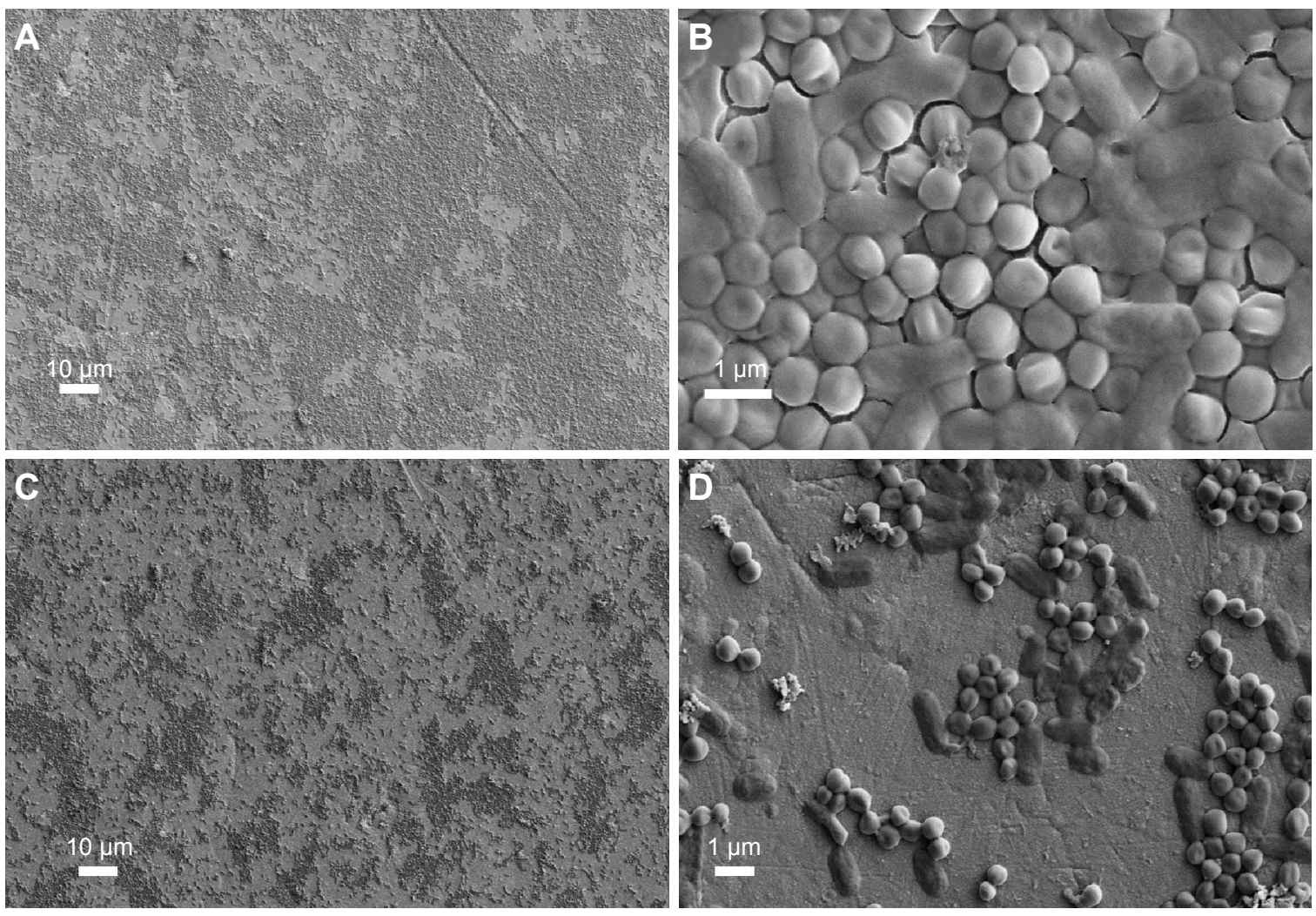

Figure 12 Field emission scanning electron micrographs showing attachment of bacteria (Escherichia coli and Staphylococcus aureus) on (A, B) stainless steel and (C, D) thin film metallic glass-coated stainless steel at different magnifications.

such as carboxylates, present in lipoproteins at the surface. ${ }^{29}$ The $\mathrm{Cu}$ ions attract the bacteria by electrostatic forces and immobilize them on the surface. $\mathrm{Cu}$ ions could also disassociate and directly exert an antimicrobial effect on the bacteria in the dispersion. Therefore, the $\mathrm{Cu}$ ion bridging between the TFMG and the bacteria play an important role in the antimicrobial activity of $\mathrm{Zr}_{48} \mathrm{Cu}_{36} \mathrm{Al}_{8} \mathrm{Ag}_{8}$ TFMG.

The release of $\mathrm{Cu}$ and $\mathrm{Ag}$ ions from the coated specimen for different time intervals was analyzed using atomic absorption spectroscopy (Table 3). The amount of metal ions
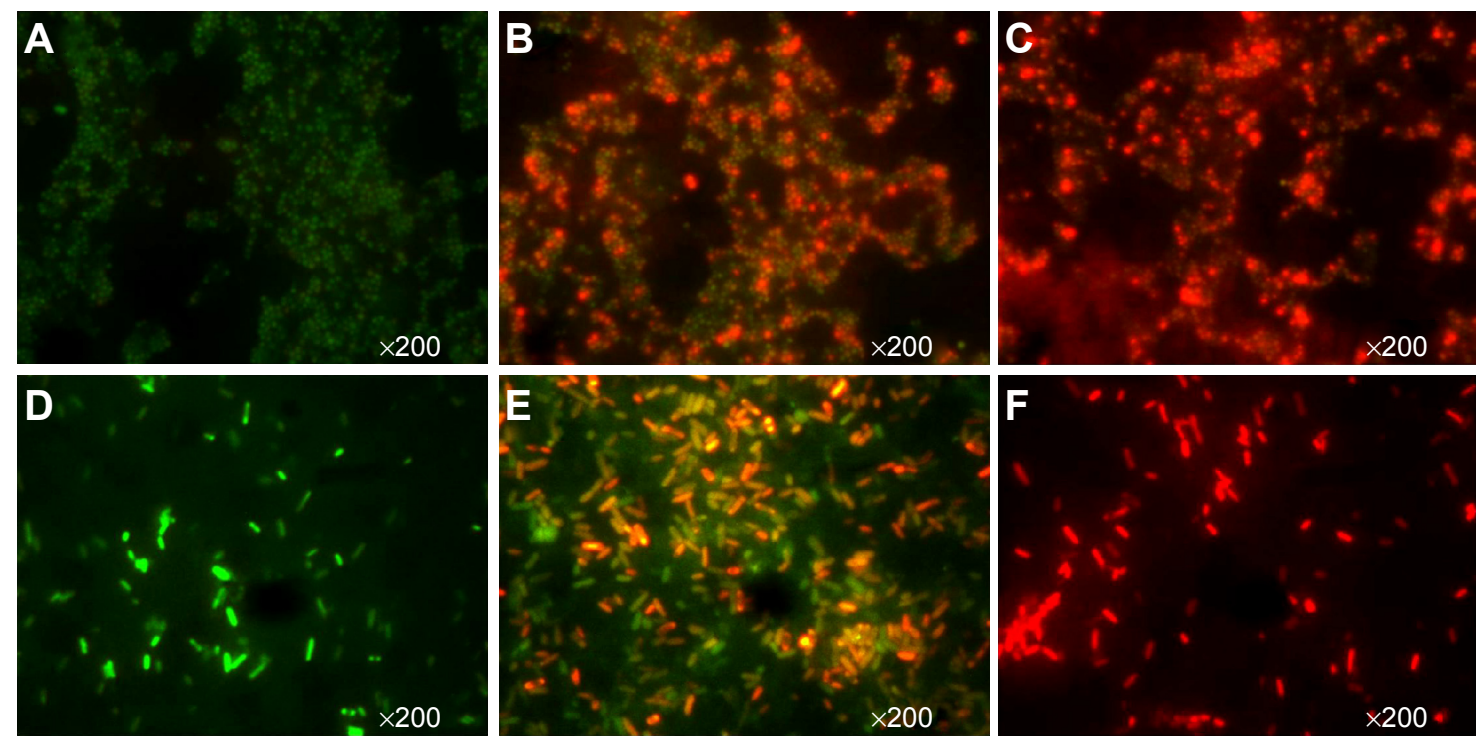

Figure 13 Epifluorescent micrographs of the killing effect on Staphylococcus aureus bacteria (A) initially and at (B) 6 hours and (C) I2 hours and the killing effect on Escherichia coli bacteria (D) initially and at (E) 6 hours (F) 12 hours. 
Table 3 Release of copper $(\mathrm{Cu})$ and silver $(\mathrm{Ag})$ ions over the time course of the experiment

\begin{tabular}{lll}
\hline Period (days) & $\mathrm{Cu}, \mathrm{mg} / \mathrm{L}$ & $\mathrm{Ag}, \mathrm{mg} / \mathbf{L}$ \\
\hline 7 & 5.7872 & 0.1152 \\
14 & 5.4298 & 0.1182 \\
21 & 6.1978 & 0.1449 \\
\hline
\end{tabular}

in milligram per liter that were leached out increased with time, thereby increasing the antimicrobial activity.

\section{Conclusion}

TFMGs of $\mathrm{Zr}_{48} \mathrm{Cu}_{36} \mathrm{Al}_{8} \mathrm{Ag}_{8}$ (at.\%) were fabricated on $316 \mathrm{~L}$ SS substrates by DC magnetron sputtering and potential biomedical application. The glassy amorphous state was confirmed by X-ray diffraction. The atomic force microscopic and SEM images revealed that the coating was uniform and homogenous, indicating no crystalline structure. An elemental composition close to that of the target alloy was noted from EDAX analysis. The $\mathrm{Zr}_{48} \mathrm{Cu}_{36} \mathrm{Al}_{8} \mathrm{Ag}_{8}$ TFMGcoated steel had good mechanical properties, including high scratch resistance and a lower Young's modulus, as observed from scratch testing and nanoindendation. Zr-based TFMG-coated steels showed greater resistance to corrosion in a simulated body fluid environment than the crystalline bare substrate. The non-cytotoxic nature of the coated specimen was confirmed using L929 cells. Bacterial attachment studies indicated that there is potential for $\mathrm{Zr}-\mathrm{Cu}-\mathrm{Al}-\mathrm{Ag}$ TFMG-coated steels to be used for bacterial destruction and disinfection.

\section{Acknowledgments}

The authors are grateful to the Council of Scientific and Industrial Research, New Delhi, for the award of a research grant (CSC 0134) under the M2D program to carry out this work and to Johnson and Johnson for sponsoring the present paper. They also thank A Kobayashi, and H Nishikawa of Osaka University, Japan, for the nanoindentation experiments. Thanks are also due to CV Muraleedharan, Sree Chitra Tirunal Institute for Medical Sciences and Technology, Thiruvananthapuram, for the cytotoxicity analysis. The authors thank Vijayamohanan K Pillai, Director of CSIRCentral Electrochemical Research Institute, and M Jayachandran, Central Electrochemical Research Institute, Karaikudi, for their ongoing encouragement.

\section{Disclosure}

The authors report no conflicts of interest in this work.

\section{References}

1. Huang CH, Huang JC, Li JB, Jang JSC. Simulated body fluid electrochemical response of Zr-based metallic glasses with different degrees of crystallization. Mater Sci Eng C. 2013;33:4183-4187.

2. Lin CH, Huang CH, Chuang JF, Huang JC, Jang JS, Chen CH. Rapid screening of potential metallic glasses for biomedical applications. Mater Sci Eng C. 2013;33:4520-4526.

3. Chen M. A brief overview of bulk metallic glasses. NPG Asia Materials. 2011;3:82-90

4. Inoue A, Zhang $\mathrm{W}$, Zhang $\mathrm{T}$, Kurosaka $\mathrm{K}$. High-strength Cu-based bulk glassy alloys in $\mathrm{Cu}-\mathrm{Zr}-\mathrm{Ti}$ and $\mathrm{Cu}-\mathrm{Hf}-\mathrm{Ti}$ ternary systems. Acta Mater. 2001;49:2645-2652.

5. Jiang QK, Wang XD, Nie XP, et al. $\mathrm{Zr}-(\mathrm{Cu}, \mathrm{Ag})-\mathrm{Al}$ bulk metallic glasses. Acta Mater. 2008;56:1785-1796.

6. Zhang W, Zhang QS, Qin CL, Inoue A. Synthesis and properties of $\mathrm{Cu}-\mathrm{Zr}-\mathrm{Ag}-\mathrm{Al}$ glassy alloys with high glass-forming ability. Mater Sci Eng B. 2008;148:92-96.

7. Zhodi H, Shahverd HR, Hadavi SM. Effect of Nb addition on corrosion behavior of Fe-based metallic glasses in Ringer's solution for biomedical applications. Electrochem Commun. 2011;13:840-843.

8. Hamano H. Fundamental studies on biological effects of dental metals: nickel dissolution, toxicity and distributions in cultured cells. $J \mathrm{Jpn}$ Stomatol Soc. 1992;59:456-478.

9. Lin $\mathrm{CH}$, Huang $\mathrm{CH}$, Chuang JF, et al. Simulated body-fluid tests and electrochemical investigations on biocompatibility of metallic glasses. Mater Sci Eng C. 2012;32:2578-2582.

10. Locci P, Lilli C, Marinucci L, et al. In vitro cytotoxic effects of orthodontic appliances. J Biomed Mater Res. 2000;53:560-567.

11. Suryanarayana C, Inoue A. Bulk Metallic Glasses. Boca Raton, FL, USA: CRC Press; 2010.

12. Liu YH, Fujita T, Hirata A, et al. Deposition of multicomponent metallic glass films by single-target magnetron sputtering. Intermetallics. 2012;21:105-114.

13. Chu JP, Huang JC, Jang JS, Wang YC, Liaw PK. Thin film metallic glasses: preparation, properties and applications. JOM. 2010; 62:19-24.

14. Chu JP, Jang JS, Huang JC, et al. Thin film metallic glasses: unique properties and potential applications. Thin Solid Films. 2012;520: 5097-5122.

15. Chu CW, Jang JS, Chen GJ, et al. Characteristic studies on the Zr-based metallic glass thin film fabricated by magnetron sputtering process. Surf Coat Technol. 2008;202:5564-5566.

16. Zhang QS, Zhang W, Louzquine-Luzgin DV, Inoue A. Effect of substituting elements on glass-forming ability of the new $\mathrm{Zr}_{40} \mathrm{Cu}_{36} \mathrm{Al}_{8} \mathrm{Ag}_{8}$ bulk metallic glass-forming alloy. J Alloys Compd. 2010;504S:S18-S21.

17. Monfared A, Faghihi S, Karami H. Biocorrosion and surface wettability of Ni-free Zr-based bulk metallic glasses. Int J Electrochem Sci. 2013;8:7744-7752.

18. Schroers J, Kumar G, Hodges TM, Chan S, Kyriakides TR. Bulk metallic glasses for biomedical applications. JOM. 2009;61:21-29.

19. Jin KF, Löffler JF. Bulk metallic glass formation in $\mathrm{Zr}-\mathrm{Cu}-\mathrm{Fe}-\mathrm{Al}$ alloys. Appl Phys Lett. 2005;86:241909-241911.

20. Buzzi S, Jin KF, Uggowitzer PJ, et al. Cytotoxicity of Zr-based bulk metallic glasses. Intermetallics. 2006;14:729-734.

21. Nwankire CE, Favaro G, Duong Q-H, Dowling DP. Enhancing the mechanical properties of superhydrophobic atmospheric pressure plasma deposited siloxane coatings. Plasma Processes and Polymers. 2011;8:305-315.

22. Kukubo T, Kushitani H, Sakka S, Kitsugi T, Yamamuro T. Solutions able to reproduce in vivo surface-structure changes in bioactive glassceramic A-W. J Biomed Mater Res. 1990;24:721-734.

23. Miller JS, Quarles JM. Flow cytometric identification of microorganisms by dual staining with FITC and PI. Cytometry. 1990;11:667-675.

24. Sharma P, Kaushik N, Kimura H, Saotome Y, Inoue A. Nano-fabrication with metallic glass - an exotic material for nano-electromechanical systems. Nanotechnology. 2007;18:035302. 
25. Cieslik M, Kot M, Reczynski W, Engvall K, Rakowski W, Kotarba A. Parylene coatings on stainless steel 316L surface for medical applications - mechanical and protective properties. Mater Sci Eng C. 2012;32:31-35.

26. Subramanian B, Ananthakumar R, Kobayashi A, Jayachandran M. Surface modification of $316 \mathrm{~L}$ stainless steel with magnetron sputtered TiN/VN nanoscale multilayers for bio implant applications. J Mater Sci Mater Med. 2012;23:329-338.

27. Nieh TG, Jankowski AF, Koike J. Processing and characterization of hydroxyapatite coatings on titanium produced by magnetron sputtering. J Mater Res. 2001;16:3238-3245.
28. Oliver WC, Pharr GM. An improved technique for determining hardness and elastic modulus using load and displacement sensing indentation experiments. J Mater Res. 1992;7:1564-1583.

29. Breen PJ, Compadre CM, Fifer EK, Salari H, Serbus DD, Lattin DL. Quaternary ammonium compounds inhibit and reduce the attachment of viable Salmonella typhimurium to poultry tissues. J Food Sci. 1995; 60:1191-1196.

\section{Publish your work in this journal}

The International Journal of Nanomedicine is an international, peerreviewed journal focusing on the application of nanotechnology in diagnostics, therapeutics, and drug delivery systems throughout the biomedical field. This journal is indexed on PubMed Central, MedLine, CAS, SciSearch $®$, Current Contents $® /$ Clinical Medicine,
Journal Citation Reports/Science Edition, EMBase, Scopus and the Elsevier Bibliographic databases. The manuscript management system is completely online and includes a very quick and fair peer-review system, which is all easy to use. Visit http://www.dovepress.com/ testimonials.php to read real quotes from published authors.

Submit your manuscript here: http://www.dovepress.com/international-journal-of-nanomedicine-journal 